PATRYCJA TRZESZCZYŃSKA

Instytut Etnologii i Antropologii Kulturowej UJ, Kraków

\title{
WIDOK I PRZESTRZEŃ. KONSTRUOWANIE KRAJOBRAZÓW W BIESZCZADACH ${ }^{1}$
}

Współczesne Bieszczady, choć w wyobraźni potocznej kojarzą się z peryferiami i dzikim zakątkiem na końcu świata, dyskursywnie wykraczają poza samo pasmo górskie na południowo-wschodnim krańcu Polski. Od czasu zakończenia wojny, wysiedleń i rozpoczęcia akcji osadniczej na szeroką skalę Bieszczady nieustająco rozpalają wyobraźnię przepracowanych mieszkańców miast, dostarczają inspiracji pisarzom i poetom, twórcom filmów i seriali, jednoczą też ambitnych turystów. Potoczne wyobrażenia o tym regionie zdominowane są przez optykę wizualną, w której centralne miejsce zajmują góry - charakterystyczne połoniny, pustkowia, łagodne szczyty, wielkie połacie lasu i zamieszkujące je dzikie zwierzęta. O Bieszczadach myśli się więc przez pryzmat krajobrazów - widoków.

Na postrzeganie Bieszczadów wpłynęła klisza dzikości i pustkowia. Wyobrażenie takie reprodukowane jest też przez hasło "rzuć wszystko i wyjedź w Bieszczady” - przed potencjalnym przybyszem otwiera się wizja oddalonej od centrum pustej przestrzeni, której przyroda przynosi natychmiastowe ukojenie. Tymczasem ani dla mieszkańców Bieszczadów, ani dla osób stamtąd wysiedlonych krajobraz nie jest pusty czy dziewiczy (por. Smyrski 2018, s. 130-131). Pozornie bezludne przestrzenie wypełniają prywatne ścieżki i „swoje miejsca” mieszkańców. Z kolei na rozległe doliny osoba wysiedlona patrzy przez pryzmat wspomnień i opowieści o tym, co było tam niegdyś. Perspektywy oglądu krajobrazów bieszczadzkich mogą być więc odmienne. Inaczej patrzy mieszkaniec, inaczej osoby wysiedlone, inaczej zaś turyści czy etnograf. Ten pierwszy nie tylko mieszka w krajobrazie, ale przede wszystkim go współtworzy.

\section{KRAJOBRAZ BIESZCZADÓW CZY KRAJOBRAZ W BIESZCZADACH? INSPIRACJE TEORETYCZNE}

Dotychczas refleksje nad bieszczadzkim krajobrazem zostały podjęte przez socjologa Krystiana Połomskiego (2010) i historyka Jarosława Syrnyka (2018). Połomski traktuje krajobraz synonimicznie z miejscem i przestrzenią, wychodzi też z założenia, że doświadczanie krajobrazu przez mieszkańców wsi położonych w pobliżu i na

\footnotetext{
${ }^{1}$ Serdecznie dziękuję dr. hab. Łukaszowi Smyrskiemu za cenne uwagi do tego tekstu.
} 
terenie Bieszczadzkiego Parku Narodowego różni się od doświadczeń pracowników parku, co wpływa na podejmowane przez niego w terenie działania i uzyskany materiał (Połomski 2010, s. 59). Zwraca jednak uwagę na istotne problemy modelujące sposoby postrzegania krajobrazu przez mieszkańców: bezrobocie, emigrację, strach przed ekspansywnymi wilkami, upadek rolnictwa, poczucie braku perspektyw ${ }^{2}$.

Z kolei Syrnyk opiera swoje rozważania na teorii aktora-sieci (ANT) Bruno Latoura. Autor stara się wyjść poza esencjalizującą matrycę historiografii narodowych i Bieszczady postrzega jako sieć relacji, w ramach której krajobraz, rozumiany jako góry, las i ziemia, jest jednym z aktorów (aktantów) i „podstawą każdej lokalnej sieci relacji w Bieszczadach" (Syrnyk 2018, s. 371). Szczególne znaczenie Syrnyk przypisuje lasom, w których chroniła się ludność cywilna i partyzanci, i które stały się miejscem konfrontacji tych, którzy chcieli przeżyć i zostać na swojej ziemi, oraz tych, którzy reprezentowali nowy ośrodek władzy. Po wysiedleniach las zaczął rozprzestrzeniać się na opuszczone tereny, co w szybkim tempie prowadziło do zanikania dawnego układu osadniczego i z czasem miało przekształcić się w kapitał turystyczny: region stał się jednym $\mathrm{z}$ najbardziej zalesionych w Polsce, ostoją wyjątkowych gatunków roślin i zwierząt, co z kolei spowodowało, że zaczął być kojarzony z atrakcyjną turystycznie dzikością (Syrnyk 2018, s.372). Obok zasobów naturalnych, które tworzą krajobraz, Syrnyk wymienia ważnych dla niego aktantów, przechowujących pamięć o dawnych Bieszczadach: granice administracyjne i państwowe (wraz z budkami strażników i zasiekami), domy i inne budynki, cerkwie, kościoły, cmentarze, krzyże przydrożne, kapliczki, szlaki kolejowe i drogi (Syrnyk 2018, s. 371-373).

Idąc dalej za inspiracjami z Latoura, można stwierdzić, że obiekty w przestrzeni stają się podmiotami, które „także posiadają sprawczość”, a każda rzecz, która wprowadza jakąś różnicę w działaniu innego podmiotu, jest aktorem (aktantem), a więc i podmiotem (Latour 2010, s. 537). Niedostrzeganie tych powiązań i wzajemnych zależności Latour wiąże m.in. $\mathrm{z}$ dominacją pozornie słusznego rozróżnienia między tym, co materialne, a tym, co społeczne, i postuluje ich splatanie, odrzucenie tego sztucznego podziału ${ }^{3}$. Nie chodzi tu jednak o ustanawianie symetrii pomiędzy tym, co ludzkie, i tym, co pozaludzkie, ale raczej o znoszenie nieuzasadnionej asymetrii między działaniem ludzi a światem materialnym (Latour 2010, s. 542-544).

Podobnie na udział rzeczy (rozumianych jako fizyczne obiekty) w życiu społecznym patrzy Bjørnar Olsen, rzecznik uznania podmiotowości i przypisania działań, intencji oraz władzy czynnikom pozaludzkim. Traktuje on rzeczy - obok ludzi, zwierząt i roślin - jako „byty w świecie” (Olsen 2010, s. 565). Ubolewa jednak, że strona materialna bytów w świecie (poza ciałem ludzkim) jest pomijana, nawet we współczesnych studiach nad krajobrazem, w których nie dość uwagi, jego zdaniem, poświęca się własnościom i zdolnościom samej materii. Są to te cechy rzeczy, „które

${ }^{2}$ Choć problemy te pojawiały się w moich badaniach, skupię się w tym tekście na zupełnie innych zagadnieniach, związanych z kształtowaniem i doświadczaniem krajobrazu w Bieszczadach.

${ }^{3} \mathrm{~W}$ takim ujęciu nie do utrzymania jest opis powiązań łączących zbiorowość w kategoriach „materialnych infrastruktur", jak lustra odbijających jedynie dystynkcje społeczne (Pierre Bourdieu) lub też jako sceny, na której występują aktorzy odgrywający swoje role (Erving Goffman) (Latour 2010, s. 557). 
nabierają mocy sprawczej poprzez konkretną ludzką obecność i intymne współistnienie ludzi z materią" (Olsen 2010, s. 573). Podejście Latoura i Olsena do rzeczy będzie mi bliskie w tej części artykułu, w której zaprezentuję perspektywę etnografki oglądającej „widoki”. Będę w niej tropić sprawczość obiektów-podmiotów i ich materialność, która jest istotnym nośnikiem informacji i co oczywiste - znaczeń. Z kolei, aby wejść w nieco bardziej intymną relację mieszkańców Bieszczadów ze środowiskiem, niezbędne jest przyjęcie perspektywy charakterystycznej dla antropologii krajobrazu.

Antropologowie zajmujący się krajobrazem zauważają, że nie sposób dziś myśleć o tej kategorii wyłącznie w ujęciu wizualnym i materialnym. Taka optyka unieruchamia krajobraz i odrywa go od żyjących w nim ludzi, podejmowanych przez nich praktyk, w tym sposobów doświadczania i konceptualizowania krajobrazu. Łukasz Smyrski, autor monografii Między władza spojrzenia a praktyką, opiera swą antropologię krajobrazu na założeniu, że:

[...] krajobraz nie istnieje obiektywnie - tworzą go jednostki wchodzące w relacje z poszczególnymi obiektami otoczenia. Tym samym stanowią go, pozostawiając w nim ślady swojej działalności. Krajobraz rozumiany etnograficznie musi być skorelowany z lokalnymi praktykami i sposobami życia (Smyrski 2018, s. 23).

Współczesne antropologiczne perspektywy badania krajobrazu (np. Hirsch, O’Hanlon 1995; Ingold 1993; Low, Lawrence-Zuñiga 2003; Tilley, Cameron-Daum 2017) kładą nacisk na jego dynamiczny, procesualny wymiar. Wpływowe pisma Tima Ingolda uczuliły badaczy na rozumienie krajobrazu nie jako czegoś gotowego, ale jako złożonego procesu, kształtowanego przez wielu twórców. W klasycznym tekście The Temporality of the Landscape Ingold wykłada swoje ugruntowane w fenomenologii rozumienie bycia w krajobrazie jako zamieszkiwania, poprzez które ludzie stają się częścią krajobrazu, a ten - częścią ich życia. Pozwala mu to odróżnić środowisko od krajobrazu poprzez umieszczenie w nim zamieszkującego człowieka i jego ciała. Jak twierdzi Ingold, krajobraz jest procesem, który zależy od ludzkiej aktywności i który na nią wpływa (1993, s. 162). Posługuje się pojęciem taskscape, pozwalającym wskazać na aktywność jednostki w ramach zamieszkiwanego krajobrazu, jej codzienne zadania oraz ucieleśnione praktyki, które w nim podejmuje (Ingold 1993, s. 157-162).

W dalszej części artykułu przyjrzę się krajobrazowi bieszczadzkiemu w dwóch wymiarach, które będą wyłaniać się z poszczególnych podrozdziałów, podzielonych problemowo. Pierwszy z nich to wymiar wizualny krajobrazu oglądanego przeze mnie $\mathrm{w}$ trakcie badań ${ }^{4} \mathrm{i}$ to, co w nim dostrzegam w kontekście informowania przybysza o przeszłości tych ziem. Moja optyka jest tu zbliżona do optyki turysty, dziennikarza

${ }^{4}$ W poniższym tekście odwołuję się głównie do materiału z lat 2016-2019 zebranego w kilkunastu miejscowościach powiatu bieszczadzkiego. Opieram się na własnych materiałach pochodzących z rozmów i notatek terenowych oraz dokumentacji wizualnej. W badaniach tych, finansowanych przez Wydział Historyczny UJ, brali udział także uczestnicy prowadzonego przeze mnie laboratorium etnograficznego. Cytat z wywiadu studenckiego opatruję „metryczką”, zawierającą informację o miejscu i roku przeprowadzonej rozmowy, numerze wywiadu, płci i wieku rozmówcy. Pozostałe cytaty bez „metryczek” pochodzą z moich notatek terenowych. 
lub fotografa - outsidera, który stara się Bieszczady „zobaczyć” i odczytać znaczenie obiektów współistniejących z górami. Będę tu zatem referować moje spostrzeżenia $\mathrm{z}$ wieloletnich obserwacji dotyczących tego, co ludzie z krajobrazem bieszczadzkim robią - restaurując zaniedbany kirkut, stawiając tablicę informacyjną albo ignorując zarastający greckokatolicki cmentarz. Pomimo formułowanych od lat 90. XX w. zastrzeżeń antropologów co do prawomocności opisu krajobrazu z perspektywy outsidera jako ujęcia statycznego, pozbawiającego aktywnego podmiotu i reprodukującego dominację wzrokocentryzmu (Smyrski 2018, s. 28-29), perspektywa taka wydaje mi się istotnym dopełnieniem podjętych refleksji, ponieważ dostarcza wiedzy o tym, jak Bieszczady może zobaczyć przybysz. Z taką perspektywą konfrontują się także mieszkańcy Bieszczadów, którzy czytają książki na temat regionu pisane przez outsiderów, oglądają filmy kręcone w Bieszczadach czy prowadzą rozmowy z turystami. Aby jednak nie mieszać tych dwóch porządków, będę stosować kategorię krajobrazu w odniesieniu do mieszkańców i ich doświadczeń, natomiast o perspektywie outsidera, w tym mojej, będę pisać, posługując się kategorią przestrzeni, mając na względzie dystans między oglądającym widok a kimś, kogo życie toczy się wewnątrz (por. Smyrski 2018).

Z kolei drugi wymiar oparty będzie na uchwyconych przeze mnie sposobach myślenia mieszkańców Bieszczadów o otaczającym ich środowisku oraz podejmowanych przez nich praktykach, poprzez które tworzą bieszczadzki krajobraz. Przyjrzę się wynikającym z mieszkania w Bieszczadach codziennym rutynowym czynnościom kilku osób, z którymi spędziłam najwięcej czasu. Refleksje dotyczące tych dwóch wymiarów poprzedzę fragmentem poświęconym kontekstowi historycznemu, bez którego trudno jest zrozumieć wizualne przemiany bieszczadzkiego krajobrazu po 1989 roku.

\section{PRZEMIANY BIESZCZADÓW - INGERENCJE W PRZESTRZEŃ, POPRAWIANIE WIDOKÓW}

Jarosław Syrnyk nazywa Bieszczady „jeszcze jedną prowincją Ziem Odzyskanych” (Syrnyk 2018, s. 371). Określenie to wydaje się niezwykle trafne. Zanim ukształtowało się współczesne oblicze kulturowe regionu, ulegał on licznym wstrząsom i niemal całkowitej depopulacji. W powiecie leskim (który przed wojną pokrywał się z dzisiejszym „turystycznym”, szerokim rozumieniem terytorium Bieszczadów) mieszkało około 70\% Rusinów (Bojków, czyli ukraińskich górali zamieszkujących m.in. Bieszczady), 10\% Żydów, 8\% Polaków, około 1\% Niemców i podobny odsetek Romów (Demel 2016). Bieszczadzcy Rusini, czyli Bojkowie, zostali wysiedleni najpierw na radziecką Ukrainę (w latach 1944-1946), pozostali zaś na północ Polski (1947 r., akcja „Wisła”). Żydzi i Romowie zostali wymordowani przez hitlerowców, tutejsi Niemcy zaś uciekli do Rzeszy. Z autochtonów po wojnie pozostali tylko Polacy. Po $1956 \mathrm{r}$. wróciły w Bieszczady nieliczne ukraińskie rodziny (Motyka 2009). Z kolei z terenów przyłączonych do Polski w ramach tzw. akcji H-T z 1951 r., czyli „regulacji odcinków granicznych” między Polską i ZSRR, władze radzieckie wysiedliły wszystkich miesz- 
kańców Ustrzyk Dolnych, Czarnej, Lutowisk wraz z okolicznymi miejscowościami, a na ich miejsce i do ich domostw sprowadzono Polaków z Sokalszczyzny, przyłączonej do ZSRR (Wójcik 2009, s. 129-130). Od końca lat 40. XX w. w Bieszczady wciąż przybywają nowi mieszkańcy, choć dziś już nie masowo, a incydentalnie.

Przemiany Bieszczadów w wymiarze materialno-wizualnym zachodziły wskutek nie tylko głębokich ingerencji w przestrzeń, związanych z powojenną modernizacją (budowa wielkiej i małej obwodnicy bieszczadzkiej, tzw. pętli, zatopienie kilku wsi pod budowę zapory na Sanie, elektryfikacja), ale i osadnictwa, pojawiania się nowych i znikania starych budynków, powstania Bieszczadzkiego Parku Narodowego (1973 r.), niszczenia i odbudowy cerkwi, usuwania śladów po byłych sąsiadach oraz działania samej przyrody.

Z końcem lat 40. ubiegłego wieku zaczęli przyjeżdżać w Bieszczady robotnicy i potencjalni osadnicy. W prasie i filmach propagandowych Polskiej Kroniki Filmowej oraz warszawskiej Wytwórni Filmów Dokumentalnych prezentowano Bieszczady jako ziemię zdziczałą, opuszczoną, pozbawioną życia i oczekującą na nowych gospodarzy:

Bezludna, milcząca ziemia. Bieszczady - czyta w pierwszych słowach lektor - tylko ślad dawnej drogi mówi, że kiedyś było tu życie ${ }^{5}$.

Odpowiedzialnością za stan regionu władze komunistyczne obarczały „faszystowskie” lub „nacjonalistyczne bandy UPA”. Śmiałkowie, którzy zdecydowali się ciężko pracować na rzecz ponownego zagospodarowania Bieszczadów, prezentowani byli w materiałach filmowych jako bohaterowie i patrioci nowej, socjalistycznej ojczyzny ${ }^{6}$. Turystom, którzy planują wyprawę w Bieszczady, radzono zaś:

Jeżeli kiedyś szlak turystycznej włóczęgi zaprowadzi cię w bieszczadzkie góry, nie pytaj napotkanych ludzi o minione lata. Ta ziemia dopiero teraz zaczyna zapominać o przeszłości. Zaczyna życie od nowa ${ }^{7}$.

Zachęcano do wypełnienia bieszczadzkiej pustki, obiecując za ciężką pracę domy, zatrudnienie i ziemię. Warto także zwrócić uwagę na to, jak pokazywana jest w tych filmach bieszczadzka przestrzeń: dominują obrazy prezentujące pustkowia, zarastające roślinnością, wyludnione, pozbawione ludzkich siedzib i śladów życia. Człowiek pojawia się w tych przestrzeniach, które już ponownie zagospodarowano: na budowie hotelu robotniczego, podczas wznoszenia zapory w Solinie oraz budowy wielkiej i małej obwodnicy albo kiedy kolejne grupy osadników trafiają na bieszczadzką ziemię.

Większość cerkwi greckokatolickich została zniszczona w czasie konfliktu polsko- ukraińskiego, a podczas wysiedleń partyzanci UPA palili ukraińskie gospodarstwa, aby uniemożliwić Polakom ich zasiedlenie. Przetrwały natomiast cerkwie i gospodarstwa na obszarze przyłączonym do Polski w 1951 r. Osadnicy z akcji H-T zasiedlili

\footnotetext{
${ }^{5}$ Opowieść o drodze, reż. Władysław Ślesicki, WFD 1958.

${ }^{6}$ Por. Życie wróciło w Bieszczady, PKF 1958; Energia [o budowie zapory w Solinie], reż. Władysław Ślesicki, WFD 1967.

${ }^{7}$ Spacer w Bieszczadach, reż. Władysław. Ślesicki, WFD 1958.
} 
domostwa, a Kościół rzymskokatolicki na przestrzeni kolejnych dekad przejmował większość cerkwi, dostosowując ich wnętrze do obrządku łacińskiego. Te, które nie zostały przejęte, stały się magazynami na zboże czy owczarniami, a wcześniej pozbawione zostały wyposażenia świadczącego o wschodnim obrządku (Kurzynoga 2009). Niszczenie cerkwi nie zakończyło się wraz z wysiedleniami, ale następowało też w latach późniejszych. Przykładem jest rozbiórka cerkwi w Lutowiskach w 1979 r. W interpretacji mieszkanki tej wsi, u której zawsze się zatrzymywałam podczas badań, cerkiew ta raziła miejscowych włodarzy, ponieważ widok wsi z pętli miał dwa dominujące punkty: kościół i cerkiew. Ten drugi obiekt jednoznacznie świadczył o tym, kto niegdyś mieszkał w Lutowiskach, symbolicznie też równoważył ten pierwszy. „Wymagał” więc interwencji.

Zasiedlano przestrzeń, która zawierała wyraźne odsyłacze do przeszłości poprzedników, do której osadnicy jakoś musieli się przystosować, choćby poprzez jej zignorowanie ${ }^{8}$. Zarastały cmentarze kryjące szczątki Ukraińców i Żydów. Nowy porządek symbolizowały w przestrzeni nowe pomniki. Powstawały więc monumenty upamiętniające milicjantów i żołnierzy poległych w walce z UPA lub „utrwalających władzę ludową" w Bieszczadach. Kręcono filmy fabularne, w których bieszczadzcy pionierzy i śmiałkowie walczyli z przyrodą i mrokami własnej przeszłości, wciąż przeczuwając obecność ukraińskiego „banderowca”, „faszysty” i „rezuna”. Negatywny stereotyp Ukraińca wzmacniany był w publikacjach prasowych oraz powieściach poświęconych walkom z UPA i postaci generała Świerczewskiego, który zginął w 1947 r. pod Jabłonkami ${ }^{10}$.

Wiele pomników z PRL-u przetrwało w Bieszczadach. Do czasu demontażu części z nich w 2018 r., żaden nie został wcześniej zniszczony. W ostatnich latach władze gmin Baligród i Cisna intensywnie poszukiwały pomysłu na rekontekstualizację upamiętnień - pomnika Świerczewskiego w Jabłonkach i pomnika poświęconego poległym w Cisnej milicjantom, nazywanego od wzgórza, w które jest wkomponowany, „Betlejemką". Ostatecznie pomnik w Jabłonkach rozebrano, a pomnik w Cisnej ma nową tablicę o treści „Obrońcom Cisnej i okolic przed Ukraińską Powstańczą Armią 1944-1947”. Co ciekawe, pierwotny projekt tablicy, przygotowany przez lokalną Fundację „Tylko Bieszczady”, nie zawierał odniesienia do UPA. Poprawkę wprowadził rzeszowski oddział IPN, zatwierdzający projekt ${ }^{11}$.

Dziś rekontekstualizacja obiektów w Bieszczadach nie zaciera ich pierwotnego znaczenia, wydaje się je wręcz uwypuklać. Ich materialność jest jasnym i jedno-

${ }^{8}$ Podobny los spotykał także polskie ślady w przestrzeni wysiedlonych wsi bieszczadzkich.

9 Np. Wilcze echa, reż. Aleksander. Ścibor-Rylski, 1968; Rancho Texas, reż. Wadim. Berestowski, 1958; Ogniomistrz Kaleń, reż. Ewa i Czesław Petelscy, 1961; Baza ludzi umarlych, reż. Czesław Petelski, 1958; Zerwany most, reż. Jerzy Passendorfer, 1963; Chudy i inni, reż. Henryk. luba, 1966; Żotnierz zwycięstwa, reż. Wanda Jakubowska, 1953.

${ }^{10} \mathrm{~Np}$. Ślady rysich pazurów Wandy Żółkiewskiej; Łuny w Bieszczadach Jana Gerharda; O człowieku, który się kulom nie kłaniał Janiny Broniewskiej.

${ }^{11}$ http://www.bieszczadzka24.pl/aktualnosci/pomnik-w-cisnej-w-nowej-odslonie/2803, dostęp 05.07.2019. 
znacznym komunikatem. Można jednak znaleźć takie obiekty, w których tkankę zaingerowano tak dalece, że pierwotny kształt i znaczenie zostały w zasadzie zatarte. W budynku dawnej synagogi na tyłach rynku w Ustrzykach Dolnych znajduje się Miejska Biblioteka Publiczna. Na zewnątrz nie ma żadnej tablicy upamiętniającej. Dostrzeże ją dopiero ktoś, kto wejdzie do środka. Z kolei z tyłu budynku widoczny jest mały fragment oryginalnej fasady. Jednak sposób wyeksponowania znaków świadczących o przeszłości obiektu można interpretować tak, że jest to przekaz skierowany do osób, które wiedzą, czego szukają.

Wciąż istnieją w Bieszczadach cmentarze, na których znajdują się groby dawnych gospodarzy. Cmentarz jest „obszarem pamięci o tym, co określało sens ludzkiego życia, co stanowiło o przynależności zmarłego do jakiejś dającej się wyraźnie określić, społeczności” (Kolbuszewski 1996, s. 33). Miejsce to stanowi dla wspólnoty rodzaj historycznego zwornika, tym ważniejszego, że ma ona pozycję mniejszościową, a cmentarz jest jednym z nielicznych miejsc nacechowanych etnicznie, czytelnym także dla sąsiadów. Stary cmentarz za cerkwią greckokatolicką w Ustrzykach Dolnych nie jest „przypisany” etnicznie tylko jednej wspólnocie. Groby ukraińskie: stare i nowe, przemieszane są z polskimi. Stare nagrobki ukraińskie, ze słabo widocznymi literami, są generalnie w lepszym stanie niż na większości „przypisanych” etnicznie Ukraińcom starych cmentarzach w Bieszczadach. Choć coraz rzadziej na płytach pojawia się cyrylica, można zorientować się po ukraińskim brzmieniu nazwisk: np. Demczuk, Wawryszczuk, Tomczyszyn, czy po imieniu - np. Paraskewia czy Wasyl. Nagrobki Ukraińców, którzy zmarli po 1951 r., a zatem już po regulacji granic, „za Polski”, są zadbane - opiekują się nimi potomkowie lub ziomkowie. Znacznie gorzej prezentują się najstarsze nagrobki. Tak więc zauważyć można tu czytelny znak wobec porządku tych, których już nie ma i którzy byli „obcy” - Ukraińcy wysiedleni do ZSRR, szacunek zaś dla grobów „naszych” Ukraińców, tych, z którymi żyjemy po 1951 r.

W przeciwieństwie do ustrzyckiego cmentarza te, które znajdują się obok dawnych cerkwi w pobliskich miejscowościach, cechuje kilka prawidłowości: dawne groby ukraińskie nie „mieszają” się z polskimi, są wyraźnie oddzielone, niszczeją. W Moczarach za dawną cerkwią (obecnie kościół rzymskokatolicki), na której nie ma żadnej tablicy informującej o przeszłym przeznaczeniu, znajduje się kilka starych, zaniedbanych i przewróconych nagrobków. Także w Łodynie (dawna cerkiew, obecnie kościół rzymskokatolicki) nie znajdziemy informacji o historii obiektu. Na cmentarzu po drugiej stronie drogi stara ukraińska część jest wyraźnie oddzielona od nowej polskiej. Wśród ukraińskich nagrobków tylko jeden jest odnowiony i w dobrym stanie. Na większości napisy są już zupełnie nieczytelne. Resztki grobów zarastają barwinkiem.

Obecność Żydów w Bieszczadach jest dziś równie słabo eksponowana, choć nie brakuje materialnych śladów po tej społeczności oraz tablic postawionych w miejscach kaźni podczas II wojny światowej. Lesko, Baligród, Ustrzyki Dolne i Lutowiska to miejscowości zamieszkane w największym stopniu przez społeczność żydowską (Potaczek 2017, s. 25). Do dziś istnieją tam kirkuty, w Lesku i Ustrzykach synagogi, a w Lutowiskach ruiny bożnicy. Stan cmentarzy jest zróżnicowany, jednak najgorzej prezentuje się kirkut w Ustrzykach. Jest on skrajnie zaniedbany, porasta go 
bujna roślinność, wiele nagrobków jest zapadniętych, a materiał uległ zniszczeniu. Napisy są nieczytelne, uszkodzone lub został po nich tyko ślad. Macewy pokrywa mech. Od 2006 r. stoi tu jednak tablica informacyjna. Zarówno sama tablica, jak i okresowe prace porządkowe to inicjatywa miejscowej szkoły. Regularność tych prac zdaje się jednak niewielka.

Interesujące są też zabiegi wokół kościoła w Brzegach Dolnych (dawnej cerkwi). Przy dzwonnicy znajduje się niewielki nagrobek ze współczesną tablicą w dwóch językach - ukraińskim i polskim. Jest to mogiła Mychajła Zubryćkiego, „proboszcza parafii Michniowiec (Ukraina) i Brzegi Dolne, ojca etnografii ukraińskiej”, jak obwieszcza tablica. Jedna z mieszkanek wsi zwróciła uwagę na to, że właściwa mogiła znajduje się nieco dalej, a sama tablica została umieszczona potajemnie w nocy przez delegację z Ukrainy. Naprzeciw mogiły, na ścianie cerkwi wisi tablica poświęcona Polakom przesiedlonym z Sokalszczyzny w ramach akcji $\mathrm{H}-\mathrm{T}$, umieszczona w tym miejscu w 50. rocznicę wydarzeń. Nie wspomina się jednak tych, którzy zostali zmuszeni do opuszczenia swoich domów zasiedlonych następnie przez Polaków z Sokala, Bełza, Krystynopola i Uhnowa. Wielokrotnie $\mathrm{w}$ terenie słyszałam o traumie wysiedleń z Sokalszczyzny i wydaje się, że wzrastająca liczba upamiętnień wpisuje się w potrzebę jej wysłowienia. Na tablicy ogłoszeń, stojącej przed wejściem na teren kościoła, umieszczono zaproszenie do udziału w trzydniowej wycieczce: „Na ziemię ojców naszych - wspomnienie. H-T 1951 r.” W programie wycieczki przewidziana była wizyta w szkole w Uhnowie, zwiedzanie pałacu Potockich w Krystynopolu ${ }^{12}$ oraz spotkanie z miejscowymi Polakami. Pamięć o wysiedleniach z Sokalszczyzny wsparta jest zatem konkretnymi, współczesnymi działaniami, nieograniczonymi do postawienia pomnika. Z kolei gablotka przy wejściu informująca o „Historii parafii rzymskokatolickiej”, wskazuje, że kościół w Brzegach Dolnych był cerkwią i że po 1951 r. ulokowano w nim magazyn gospodarczy. Nie znajdziemy tu jednak wyjaśnienia dziejów obiektu. Patrząc na wszystkie cztery wspomniane elementy trudno znaleźć jakąkolwiek korespondencję między nimi. Bez uprzedniego przygotowania historycznego nie sposób zorientować się w chronologii i logice upamiętnianych wydarzeń.

Inną strategię podją̨ twórca „Ekomuzeum Hołe”13 w Dźwiniaczu Dolnym i okolicznych wsiach. Umieścił tablice z wyjaśnieniem dziejów obiektów przy cerkwiach, cerkwisku, kapliczce greckokatolickiej, urządzeniach do wydobywania ropy naftowej czy słupach granicznych w miejscu, gdzie w latach 1946-1951 przebiegała granica między Polską i ZSRR. Ponadto włącza on mieszkańców w przygotowywanie prezentacji, warsztatów i pokazów dla turystów, wyjaśniających dzieje regionu. Jest to jednak jedna z niewielu inicjatyw tego rodzaju.

Mocne osadzenie powyższych refleksji w geografii, w fizycznym wymiarze interesującego mnie obszaru wynika także z moich terenowych doświadczeń. Podczas

${ }^{12}$ Znaczące jest to, że miasto to funkcjonuje w praktykach upamiętniania przesiedleńców z akcji H-T jako polski Krystynopol, a nie współczesny ukraiński Czerwonograd. Inną sprawą jest, że Czerwonograd to modelowe radzieckie miasto, w dodatku górnicze, dobudowane w latach 50 . XX w. przy dawnym „pańskim” Krystynopolu, w związku z powstawaniem kopalń węgla kamiennego.

${ }^{13}$ Jej pomysłodawca lokalną nazwę terenową zaczerpnął z języka ukraińskiego. Hołe - czyli gołe, puste. 
badań niezliczoną ilość razy przekonałam się, jak mocno zakorzenione jest wśród mieszkańców Bieszczadów myślenie o regionie przez pryzmat mapy. Kiedy wyjaśniano mi coś lub dokądś odsyłano, zawsze działo się to z pomocą mapy (mojej lub gospodarza). Mapy gór, powiatu leskiego czy bieszczadzkiego, schematy szlaków, mapy Bieszczadzkiego Parku Narodowego, mapy prezentujące nieistniejące wsie lub miejscowości zasiedlone w trakcie akcji $\mathrm{H}$ - T - to stały element obecny w przestrzeni, wewnątrz lub obok budynków urzędów, bibliotek, szkół, na szlakach i przy cerkwiach, w schroniskach, w obiektach agroturystycznych, hotelach i pensjonatach. Wizualna dominanta w myśleniu o przestrzeni regionu oraz wszechobecność map wydaje mi się niezmiernie istotnym kontekstem konstruowania bieszczadzkiego krajobrazu przez mieszkające w regionie osoby, którego nie sposób pominąć w prezentacji lokalnych konceptualizacji Bieszczadów. Czym innym jest natomiast oddzielenie emicznej perspektywy od spojrzenia outsidera, „konsumenta” map, który tylko pozornie widzi to samo, co jego rozmówca.

\section{ŻYCIE W KRAJOBRAZIE}

Geografia Bieszczadów przestaje być „obiektywna” i „naturalna”, odrywa się też od mapy (która także obiektywna nie jest), kiedy przyjrzymy się lokalnym sposobom doświadczania przestrzeni. Pozwolą one zauważyć, że w takiej perspektywie krajobraz staje się „aktywnie kształtowanym procesem życiowym”, w miejsce zewnętrzności czy fizycznej ramy lokalnego życia (Smyrski 2018, s. 136-137). Aby „zobaczyć” krajobraz antropologicznie, trzeba zatem porzucić wzrokocentryzm, a skupić się na praktykach mieszkania w miejscu, na tym jak Bieszczady istnieją w wiedzy i wyobrażeniach mieszkańców.

Wyobrażenia te przekraczają estetykę, odrywają się od obiektów w przestrzeni i oscylują wokół innych kategorii, które niosą znaczenie. Poniżej przybliżę kilka przykładowych aspektów związanych z doświadczaniem życia w Bieszczadach. Rozważania te nie wyczerpują rzecz jasna tematu, pokazują jedynie wybrane zagadnienia, na które szczególną uwagę zwracali mi moi najważniejsi partnerzy terenowi w osobach Marii i Pawła oraz Anki i Marioli ${ }^{14}$. Ich doświadczenia nie są odosobnione. Ze wskazanymi niżej aspektami życia w Bieszczadach stykałam się w rozmowach wielokrotnie. Stale przewijały się w nich następujące wątki: 1) poczucie życia na peryferiach, na końcu świata - rozmaicie wartościowane, ale generalnie z dwu perspektyw: jako korzyść i źródło życiowego komfortu lub jako „dopust boży”; 2) związany z poprzednim aspekt odległości i ich konsekwencje dla codzienności mieszkańców; 3) różnie konceptualizowany brak (perspektyw, zasobów, kapitałów, możliwości) oraz 4) granica.

Zacznę od znaczenia odległości w życiu Anki i jej rodziny. Mieszkają po drugiej stronie pętli, we wsi, która jest siedzibą gminy. Anka trafiła w Bieszczady z Warszawy,

${ }^{14}$ Imiona fikcyjne. Celowo także anonimizuję nazwy miejscowości, w których mieszkają moi współpracownicy i których doświadczenia tu prezentuję. 
gdzie na studiach w latach 90. poznała swojego obecnego męża, który jest spod Ustrzyk Dolnych. Wspólnie kupili ziemię poza rodzinną wsią męża i zbudowali dom. Czas pracy dzielą między wynajem pokoi turystom oraz działalność twórczą. Córkę codziennie zawożą do odległej o kilkanaście kilometrów szkoły. Z poprzedniej, bliższej, zrezygnowali, ponieważ źle się w niej czuła. Mąż i córka przynajmniej raz w tygodniu chodzą w góry. Robią to inaczej niż turyści - wychodzą na szlak późnym popołudniem albo pod wieczór - wówczas z latarką - trasy znają doskonale, często też zbaczają ze szlaku. Anka też ma swoje miejsca, których nie zdradza przybyszom. Kiedy pod koniec września wybrałam się do Worka Bieszczadzkiego na rower, po drodze, jadąc ścieżką konną, znalazłam kilka dorodnych prawdziwków. Po moim powrocie Anka obejrzała łup, wyjęła mapę i zażądała pokazania jej o którą ścieżkę chodzi. Przyznała, że włączy to miejsce do swoich poszukiwań. Jednocześnie nie chciała pokazać mi, gdzie sama wybiera się na grzyby. Zrozumiałam, że przyjezdnym nie zdradza się takich tajemnic, a równocześnie można ich tropy włączyć do swoich i czegoś się od nich nauczyć. Anka postawiła mi tu wyraźną granicę.

Rodzina ma liczne kontakty towarzyskie i wielu przyjaciół w okolicy, na spotkania z którymi poświęcają każdą wolną chwilę. Anka stale też musi dokądś po coś podjechać, niemal nie gasi silnika samochodu. Codzienne pokonywanie tych samych tras i ciągłe krążenie po „tej stronie pętli” jest nieodłącznym elementem jej życia. Konieczność bycia kierowcą w Bieszczadach jest dla Anki oczywista i nie da się jej pominąć, jeśli chce się być samodzielnym. W sytuacji bardzo ograniczonego transportu publicznego w Bieszczadach pozostaje jedynie samochód, który pozwala mieszkańcom „normalnie funkcjonować i pchać to życie do przodu” ${ }^{15}$. Anka ubolewa nad tym, że wiele mieszkanek Bieszczadów nie ma prawa jazdy. Ciekawy jest w jej opinii wpływ mobilności kobiet na poziom życia w Bieszczadach w ogóle. Ich transportowa samodzielność pozwala im podjąć zatrudnienie lub prowadzić własną firmę. Brak prawa jazdy i własnego samochodu zamyka kobiety w domach i w sytuacji konieczności wyjazdu do lekarza, po zakupy lub do fryzjera skazuje je na dobrą wolę bliskich lub sąsiadów, odbierając im tym samym sprawczość. Brak mobilności kobiet oznacza także, że rzadko bywają poza własną wsią.

Podobnie jak Anka, także Mariola swojego męża poznała na studiach i postanowiła „za nim” przyjechać w Bieszczady. Podkreślała, że w pierwszych latach swojego związku z mężem odwiedzała Bieszczady jak turystka i jak turystka je oglądała. Perspektywa ta stopniowo zaczęła się zmieniać w miarę upływu czasu i wraz ze „spowszednieniem” odwiedzanych miejsc. Spędzając w Bieszczadach coraz więcej, czasu Mariola powoli zaczynała je postrzegać inaczej: „Góry stają się trochę niewidoczne, nie jest to już to pierwsze, co zauważysz, kiedy patrzysz przed siebie. Widzisz już inne rzeczy”.

${ }^{15}$ Najbliższy, właściwy dla powiatów leskiego i bieszczadzkiego ośrodek ruchu drogowego znajduje się w Krośnie. Kursy prawa jazdy w miejscowych szkołach nauki jazdy przebiegają więc w taki sposób, że kursant podczas lekcji praktycznych ma mało możliwości, aby uczestniczyć w ruchu w większym mieście, ponieważ godziny przeznaczone na naukę „wyjeździ” po drodze do Krosna. 
Kwestia transportu i problemy natury komunikacyjnej stanowią istotne zagadnienie związane $\mathrm{z}$ doświadczeniem życia w Bieszczadach. Widać to na przykładzie zwyczajnych zakupów. Anka zwróciła mi uwagę, że wyjazdy na zakupy z dalszej części Bieszczadów do Ustrzyk Dolnych - w praktyce do lokalnej Biedronki - ludzie organizują zwykle co dwa tygodnie. Przywożą wówczas cały samochód towarów, w tym zapas pieczywa, które zamrażają. Zaprzyjaźniona piekarnia i wiele podobnych w regionie skazane są na zamknięcie. Wybiórczy dostęp do poszukiwanych produktów na miejscu we własnej wsi lub ścisłej okolicy, mały wybór w miejscowych sklepach, a przede wszystkim wyższe ceny zmuszają ludzi do robienia rzadszych, za to większych zakupów w mieście i ograniczania się do zakupu na miejscu jedynie niezbędnych drobiazgów. Przemiany gospodarki zakupowej w regionie związane są więc nie tylko z ekonomią, ale i ponownie kwestią odległości.

Przejazd całą wielką pętlą bieszczadzką z Leska przez Ustrzyki Dolne, Ustrzyki Górne, Cisną i Baligród zajmuje prawie 2,5 godziny i liczy niemal $150 \mathrm{~km}$. Choć „na zewnątrz" Bieszczady prezentowane są jako monolit, w doświadczeniu mieszkańców funkcjonuje wyraźny podział na „naszą" i „tamtą" stronę pętli. Mieszkanka Lutowisk opowiadała mi o swoich sposobach spędzania wolnego czasu: chodzi po górach z rodziną, jesienią zbiera grzyby, odwiedza znajomych, czasem wybiera się na koncert czy do kina w Ustrzykach Dolnych. Wszystko dzieje się „po tej stronie pętli”. Rozmówczyni żachnęła się, kiedy zapytałam, czy bywa na koncertach w knajpach w Cisnej albo Wetlinie: „Eee, nieeee, tam to my nie jeździmy. To tamta strona pętli”. Jak odległa od jej codzienności jest ta druga część bieszczadzkiej obwodnicy, świadczy również to, że nie słyszała o wielu wydarzeniach i inicjatywach mających miejsce po drugiej stronie pętli, choć, jak mnie zapewniała, jest żywo zainteresowana tym, co się dzieje $\mathrm{w}$ regionie. $Z$ przekonaniem o istnieniu tak wyraźnej różnicy między obiema częściami Bieszczadów spotkałam się w terenie wielokrotnie.

Obok odległości bardzo ważnym aspektem doświadczania i bycia w krajobrazie jest dla mieszkańców bliskość granicy państwowej: „my tu mamy Ukrainę”. Można taką deklarację rozumieć dosłownie jako wskazanie na bliskość przejścia granicznego oraz widoczność ukraińskich wsi i gór na horyzoncie. Można także odczytywać to zdanie metaforycznie - Ukraina jako synonim peryferii, końca świata, wolniejszych przemian, trudów transformacji czy wręcz nieudanych przemian albo odmiennego niż w centrum porządku.

Granica południowa postrzegana jest przez mieszkańców zupełnie inaczej, szczególnie po 2007 r. (wejście Polski do strefy Schengen), ale także z tego powodu, że najbliższe przejście graniczne ze Słowacją znajduje się w Radoszycach (gmina Komańcza). Od 2008 r. można szlakiem górskim legalnie zejść do słowackiej wsi, ale nie jest to granica, z której czerpie się korzyści ekonomiczne czy choćby symboliczne. W przypadku granicy polsko-ukraińskiej jest inaczej. Jest ona stale przekraczana zarówno przez Polaków, jak i Ukraińców z pobliskich miejscowości po drugiej stronie granicy, pomimo obiektywnie większej trudności administracyjnej z tym związanej. O ile więc granica ze Słowacją wydaje się w doświadczeniu mieszkańców nieobecna czy nieistotna, o tyle granica z Ukrainą ma duże znaczenie. Dla wielu jest 
znaczącym obszarem, z bliskości którego czerpią lub czerpali do niedawna korzyści materialne (handel, przemyt).

Pomimo pozornej „przepuszczalności” granicy polsko-ukraińskiej, dla niektórych mieszkańców pozostaje ona - jak w czasach ZSRR - linią, której nie da się przekroczyć, za którą rozciąga się nieznany świat. Maria przez kilka lat, kiedy ich odwiedzałam, nie miała paszportu. Nigdy nie była na Ukrainie, choć stale jeździ tam jej syn, czasem mąż. Nie jest to sytuacja nietypowa. Żeby wyrobić paszport, należy udać się do urzędu wojewódzkiego w Krośnie, często ponad 100 km. Konieczna jest zatem silna motywacja. Jej brak powoduje, że mimo geograficznej bliskości, często dosłownie kilku kilometrów, granica stanowi barierę trudną do przebycia.

\section{KONSTRUOWANIE „BIESZCZADZKOŚCI” JAKO WIDOKU}

Na sposób postrzegania Bieszczadów - jako widoków - wpłynęła m.in. twórczość dwóch zespołów z nurtu poezji śpiewanej, Wolnej Grupy Bukowina oraz Starego Dobrego Małżeństwa. W tekstach ich piosenek, opartych na wierszach m.in. Wojtka Belona i Edwarda Stachury, krajobraz Bieszczadów poddawany jest poetyckiej interpretacji. Motywy wędrowania bezkresną połoniną, zielonej bukowiny, bieszczadzkich aniołów czy bieszczadzkiej biografii na przykładzie Majstra Biedy stale i nieprzemijająco zasilają lokalną ofertę koncertowo-festiwalową, gastronomiczną i kawiarniano- pubową oraz przemysł pamiątkarski. Lokalna poetycka interpretacja krajobrazu Bieszczadów przejawia się także w twórczości poetów i wokalistów występujących w bieszczadzkich knajpach. Podobnie, utrwalone sposoby wyobrażania krajobrazu Bieszczadów reprodukuje lokalna twórczość plastyczna: obrazy przedstawiające lasy, połoniny, konkretne widoki ze szczytów, rzeźby, obrazy cerkwi lub zawierające motywy cerkiewne (sygnaturka wieńcząca cerkiewną banię czy krzyż z poprzeczną belką). Twórczość taką można różnie oceniać pod kątem estetycznym i widzieć jako odpowiedź na gust i potrzeby turystów. Jednak w wielu przypadkach kryje się za nią indywidualna poetycka interpretacja twórców, sposób postrzegania krajobrazu, relacje z nim, związki z przeszłością, czy przywiązanie do swojego miejsca.

W interpretacji bieszczadzkich widoków ważne miejsce zajmuje klisza „dzikich Bieszczadów”. Wykorzystywana jest ona przez wiele bieszczadzkich biur podróży, które na niej budują swoją ofertę, proponując turystom przede wszystkim kontakt $\mathrm{z}$ przyrodą ${ }^{16}$. Bieszczady $\mathrm{w}$ takiej interpretacji to region na końcu świata, „dziki wschód", bezludne i nieodkryte przestrzenie. Pomija się tu mieszkańców, którzy albo żyją tu od pokoleń, albo przybyli kilkadziesiąt lat temu i dawno już „odkryli” Bieszczady. Korzystają one także z tego, jaki obraz Bieszczadów wykreował niezwykle w ostatnich latach popularny serial HBO Wataha ${ }^{17}$. „Odkrywanie dzikich

${ }^{16}$ Np. https://dzikie-bieszczady.com/, dostęp 28.10.2019.

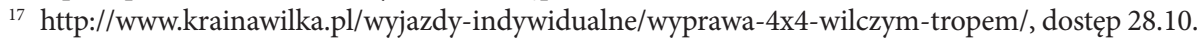
2019. Na fali popularności serialu na bieszczadzkich straganach pojawił się wysyp koszulek z motywem wilka lub napisem „Wataha”. 
Bieszczadów" staje się dla turystów coraz łatwiejsze, nie tylko z uwagi na pomoc technologii, ale także przez poprawę infrastruktury turystycznej i poprowadzenie znakowanych szlaków i ścieżek. Przykładem może być tu szlak do tzw. Grobu Hrabiny w Worku Bieszczadzkim. Niegdyś było to kultowe miejsce uczestników kursów SKPB, a dotarcie do niego było elementem przewodnickiego „chrztu”, wymagało znakomitej orientacji w terenie i umiejętności posługiwania się mapą i kompasem. Dziś jest to oznakowana ścieżka, która nie wymaga żadnych wtajemniczeń.

Z konstruowaniem widoków wiążą się także zabiegi wytwarzania miejsc przez mieszkańców. Są one usensownione i symboliczne, mają komunikować, w jakim regionie się znajdują i odsyłać do wyobrażonej „bieszczadzkości”. Takie miejsca to domy, lokale gastronomiczne, galerie sztuki i pracownie, mała architektura (szyldy, reklamy, kapliczki, elementy dekoracyjne w obejściu), domki i pokoje dla turystów - miejsca, które widać, do których można podejść lub wejść, które mają swoją materialność. Poza nimi znajdują się prywatne przestrzenie, niewystawione na widok. Jak mocno „niebieszczadzkie” mogą one być, przekonałam się wiele razy podczas obserwacji i rozmów prowadzonych w galeriach czy restauracjach. Właściciele prezentowali obiekty, opowiadali o tym, jak "udało się stworzyć bieszczadzki klimat”, ale byli wyraźnie skonsternowani, kiedy chciałam obejrzeć ich dom albo inną część pracowni czy knajpy, niedostępną dla turystów. W Bóbrce lokalny artysta starał się przede wszystkim skupić na przestrzeni publicznej, ograniczył się do „widoku” wsi i własnej pracowni. Niechęć do pokazania prywatnej przestrzeni argumentował tym, że „w domu nie ma nic ciekawego, natomiast pracownia jest bieszczadzka”. Zwracał uwagę na znajdujące się w środku rzeźby, narzędzia leżące w nieładzie, żyrandol z rogów jelenia i surowe drewniane meble. Podobnie konstruowanie „bieszczadzkiego klimatu" opisywał właściciel pensjonatu w Cisnej, przybyły kilkadziesiąt lat temu z miasta. Na poczucie, że coś jest „bieszczadzkie”, składa się jego zdaniem kilka elementów: drewno, pewna surowość i nawiązanie do czasów „kowbojskich” i „pionierskich”. Idealną realizacją stylu bieszczadzkiego są według niego nieliczne już chyże bojkowskie oraz budowane po wojnie domy pracowników leśnych, a w nowszych czasach ranczo, ponieważ najlepiej wpisują się w bieszczadzki krajobraz, są „drewniane” i „naturalne”. Starsza mieszkanka Cisnej była jednak zakłopotana, kiedy przyznała, że niektórych przybyszów zachwycają stare zabudowania i tym właśnie jest dla nich „klimat bieszczadzki”.

Tak, niektórym się podoba, bardzo się podoba. Jeszcze ta stajnia co tam stoi, wie pani. Dwie czy trzy były wtedy. „Niech pani nie rozbiera, my sobie zdjęcia zrobimy”, tam porozwalane, a tu zdjęcie sobie zrobili. „Niech pani tego nie rozbiera, przeciez to takie ładne jest, to zabytkowe”. No i takie będzie stało. Tak zdjęcie sobie zrobili. Dla mnie taki wstyd, bo to takie... (kobieta, 1. 60, Cisna, 2013).

Mieszkańcy mogą mieć zatem zupełnie inne poczucie tego, co jest bieszczadzkie, a co nie i wyraźnie rozgraniczać „bieszczadzkość” dla turystów od tej konstruowanej na własne potrzeby. Może być to dom z drewna, adaptacja starej chyży albo willa w miejskim stylu, pomalowana na jaskrawy kolor, która wyraża ich status społeczny 
i poczucie estetyki. Nie brakuje też $\mathrm{w}$ regionie odniesień pochodzących $\mathrm{z}$ innych kontekstów. Na przykład może być to nawiązujący do stylu norweskiego dom $\mathrm{z}$ bali $\mathrm{z}$ dachem porośniętym trawą, ozdobiony figurami trolli w Cisnej, domy inspirowane współczesną architekturą podhalańską, Zajazd Kresowy Chreptiów w Lutowiskach, nawiązujący do scenografii filmu Pan Wołodyjowski, czy eklektyczne wille $\mathrm{z}$ wielką liczbą łamań, wieżyczek i okien jak Zajazd Bieszczadzka Ostoja w Hoszowie. Powszechna jest krytyka takich obiektów ze strony moich rozmówców jako „gargameli” i „zakopiańszczyzny”, które zaburzają widoki. Anka ze swadą opowiadała mi, że kiedyś po drodze do miasta wzięła autostopowicza: „taki lokalny pijaczek, wiesz, ledwo mamrotał, ale jak zobaczył Ostoję, to się od razu ożywił i powiedział bardzo składnie i wyraźnie: «Patrz pani, jakie to brzydkie...!»". Jednocześnie wiele takich obiektów cieszy się dużym zainteresowaniem gości. Ich „bieszczadzkość” jest więc kontekstowa i „stopniowalna”, a w zależności od tego, kto patrzy - może zobaczyć jej esencję albo zaprzeczenie. Dotyczy to zarówno przybyszów, jak i mieszkańców.

W konstruowanie widoków wpisuje się też wykorzystanie odniesień i obiektów z przeszłości. Przepracowanie i oswojenie „obcej” przeszłości widocznej w krajobrazie może także uruchomić potrzebę zadbania o jej ślady i ich ekspozycję. Takimi śladami w Bieszczadach, które w ostatnich latach poddawane są zabiegom konserwacji, są cerkwie, cmentarze, synagogi, chyże bojkowskie czy pomniki z czasów PRL. Zaczynają być przedmiotem dyskusji i działań, otrzymują nowe funkcje, włączane są w nowe konteksty (Trzeszczyńska 2016). Olsen twierdzi, że „mimo czasowych nieciągłości $\mathrm{w}$ relacjach z człowiekiem rzeczy is $\mathrm{t} \mathrm{n}$ i e j ą i można podchodzić do nich wciąż na nowo, tak by stały się konstytutywne dla działań i wspomnień" (Olsen 2018, s. 92, podkr. w oryg.). W ostatnich latach zaobserwować można próby pokonywania takich czasowych nieciągłości i nowego odczytywania śladów po dawnych gospodarzach.

\section{KONKLUZJE}

Podjęta wyżej próba krytycznej analizy bieszczadzkich krajobrazów oparta jest na dwóch perspektywach: zewnętrznej i wewnętrznej, właściwej dla przybysza i dla mieszkańców. Pierwsza to także perspektywa etnografki, która ogląda „widoki”, ale też dostrzega sprawczość obiektów-rzeczy współuczestniczących w wytwarzaniu krajobrazu. Próba zbliżenia się do intymnej relacji mieszkańców ze środowiskiem, właściwej dla drugiej perspektywy, została zilustrowana kilkoma aspektami tej relacji, uchwyconymi w terenie. Uwzględnienie kontekstu historycznego pomaga z kolei prześledzić sposoby kształtowania się potocznych wyobrażeń o Bieszczadach, które wciąż wydają się atrakcyjne dla osób z zewnątrz i z którymi stykają się przecież mieszkańcy regionu.

Choć widoki są częścią życia mieszkańców - aktywnych twórców, ich perspektywa znacząco różni się od turystycznego oglądania widoków. To przede wszystkim codzienne zadania i ucieleśnione praktyki, które powodują, że doświadczanie krajobrazu ma wymiar głęboko cielesny, fizyczny, wiąże się z pokonywaniem odległości, 
przekraczaniem barier i granic, wymuszoną mobilnością lub jej brakiem, wynikającym ze splotu okoliczności, odczuwania rozmaitych braków i trudności. Przekracza to wymiar estetyczny, wizualny, nawet jeśli wielu mieszkańców zajętych jest konstruowaniem widoków na użytek przybyszów i na własne potrzeby. Krajobraz Bieszczadów nie jest ramą ich życia, ale ważnym aktorem, obecnym w sieci relacji, które tworzą i w których toczy się ich życie.

\section{LITERATURA}

Demel Grzegorz 2016, Sytuacja narodowościowa w okresie międzywojennym, [w:] J. Wolski (red.), Bojkowszczyzna zachodnia - wczoraj, dziś i jutro, t. 1, Instytut Geografii i Przestrzennego Zagospodarowania PAN, Warszawa, s. 457-471.

Hirsch E ric, O' Ha nlon Mich a el (red.) 1995, The anthropology of landscape. Perspectives on place and space, Clarendon Press, Oxford.

Ingold Tim 1993, The temporality of the landscape, World Archaeology, t. 25, z. 2, s. 152-174.

Kolbuszew ski Jacek 1996, Cmentarze, Wydawnictwo Dolnośląskie, Wrocław.

Kurzynoga Olga 2009, Utracone dobra kultury w Bieszczadach w latach 1944-1989 (zarys problemu), [w:] J. Izdebski, K. Kaczmarski, M. Krzysztofiński (red.), Bieszczady w Polsce Ludowej 1944-1989, Instytut Pamięci Narodowej, Rzeszów, s. 389-430.

L a t o u r B r u n o 2010, Przedmioty także posiadają sprawczość, [w:] Ewa Domańska (red.), Teoria wiedzy o przeszłości na tle współczesnej humanistyki. Antologia, tłum. A. Derra, Wydawnictwo Poznańskie, Poznań.

Low Setha M., Lawrence-Zún ig a D e nise (red.) 2003, The anthropology of space and place: locating culture, Blackwell, Oxford.

Motyka Grzegorz 2009, W kręgu „Łun w Bieszczadach”. Szkice z najnowszej historii polskich Bieszczad, Rytm, Warszawa.

Olse n B jørnar 2010, Kultura materialna po tekście: przywracanie obecności rzeczom, [w:] E. Domańska (red.), Teoria wiedzy o przeszłości na tle współczesnej humanistyki. Antologia, Wydawnictwo Poznańskie, s. 561-592.

Ol s e n B jør n a r 2018, Jak rzeczy pamiętają, [w:] P. Majewski, M. Napiórkowski (red.), Antropologia pamięci. Zagadnienia i wybór tekstów, Wydawnictwo Uniwersytetu Warszawskiego, Warszawa, s. 85-96.

Poło m ski Krystian 2010, Miejsce i przestrzeń. Krajobraz w doświadczeniu mieszkańców Bieszczadzkiego Parku Narodowego, Wydawnictwo Scholar, Warszawa.

P o t a c z e k J o a n n a E. 2017, Społeczność żydowska w Bieszczadach w latach 1918-1939 i jej losy podczas II wojny światowej, praca doktorska, repozytorium Uniwersytetu Rzeszowskiego, https:// repozytorium.ur.edu.pl/handle/item/3435.

S myrski Łukas z 2018, Między władza spojrzenia a praktyka. Antropologia krajobrazu, Oficyna Naukowa, Warszawa.

Syrnyk Ja ro sław 2018, Trójkąt bieszczadzki. Tysiąc dni i tysiąc nocy anarchii w powiecie leskim 1944-1947, Libra, Rzeszów.

Trzes z c zyńs k a P at r y cja 2016, Pamięć o nie-swojej przeszłości. Przypadek Bieszczadów, Wydawnictwo Uniwersytetu Jagiellońskiego, Kraków.

Wó j c i k Z b i g n i e w K. 2009, Zmiana granicy wschodniej Polski Ludowej w 1951 r., [w:] J. Izdebski, K. Kaczmarski, M. Krzysztofiński (red.), Bieszczady w Polsce Ludowej 1944-1989, Instytut Pamięci Narodowej, Rzeszów, s. 125-130.

Tilley Christopher, Cameron-Daum Kate 2017, An anthropology of landscape: the extraordinary in the ordinary, UCL Press, London. 


\section{Źródła internetowe}

www.dzikiebieszczady.pl (Biuro Podróży Dzikie Bieszczady), dostęp 28.10.2019. www.krainawilka.pl (Biuro Podróży Kraina Wilka), dostęp 28.10.2019.

https://nowiny24.pl/ostatnie-chwile-slynnego-pomnika-gen-karola-swierczewskiego-w-jablonkachw-bieszczadach-dzis-ma-ruszyc-rozbiorka/ar/12949195 (portal regionalny Nowiny24), dostęp 05.07.2019.

http://www.bieszczadzka24.pl/aktualnosci/pomnik-w-cisnej-w-nowej-odslonie/2803 („Gazeta Bieszczadzka"), dostęp 05.07.2019.

\section{PATRYCJA TRZESZCZYŃSKA}

\section{VIEW AND SPACE. ON CONSTRUCTING LANDSCAPES IN THE BIESZCZADY REGION}

Keywords: landscape, Bieszczady, view, place, space

The article is devoted to the problem of constructing landscapes on the example of a Polish region which in the common imagination is strongly grounded as series of views. The author uses the theoretical findings of landscape anthropologists and discusses different modes of constructing local landscapes. Two general perspectives have been confronted here: guest/outsider and inhabitant/insider. The first is also the perspective of the ethnographer who looks at "views", but also perceives the agency of objectsthings that participate in the production of the landscape. The relationship of inhabitants with the environment, appropriate for the second perspective, was illustrated by several aspects of this relationship, captured in the field and intertwined with the experience of space by residents. The construction of Bieszczady landscapes takes place through things and objects, by shaping places and by using references and objects from the past.

Adres Autorki:

dr hab. Patrycja Trzeszczyńska

Instytut Etnologii i Antropologii Kulturowej UJ

ul. Gołębia 9, 31-007 Kraków

E-mail: patrycja.trzeszczynska@gmail.com

ORCID: 0000-0002-5430-243X 